\title{
The Founding of Singapore and the Chinese Kongsis of West Borneo (ca.1819-1840)
}

\author{
Ying-kit CHAN*
}

\begin{abstract}
Many historians have examined why Singapore failed to be a major trading center before the nineteenth century. This paper revisits the current scholarly literature on the founding of Singapore to make two arguments. First, I argue that we cannot understand the founding of Singapore and its role in the British Second Empire without delineating Singapore's role as a forest- and marine-goods metropolis in the precolonial Chinese trading networks of Southeast Asia. Second, I try to show how the Chinese kongsis 公司 of West Borneo turned Singapore into a forest- and marine-goods metropolis, formed their own political and social institutions, and collectively functioned as a third autonomous pseudostate power alongside the British and the Dutch. This reconceptualization enables us to see the founding of Singapore as a joint enterprise, and not a solely British achievement.
\end{abstract}

Keywords: British Empire, Chinese kongsis, forest and marine goods, Singapore, West Borneo

\section{Introduction}

Britain contested with France for naval mastery in the Atlantic, the Mediterranean, and the Indian Ocean in the eighteenth century. At the end of the Seven Years' War (1756-1763), the main reservoirs of British strength in the Indian Ocean were in Bengal and on the Coromandel Coast. The Seven Years' War and subsequent wars between the British and French were fought in continental Europe, Canada, the West Indies, India, and the Philippines. From these experiences, the British realized that their economic and military security rested on a continental balance of power and global naval supremacy. It became obvious that to defend India from French ambitions, the British required an all-year lease in the Bay of Bengal, but the British hold on the Dutch base at Trincomalee was a precarious one. The Dutch, uninvolved in the Seven Years' War, were on the French side in the next War of

\footnotetext{
* PhD student, Department of East Asian Studies, Princeton University
} 
American Independence (1778-1783). The initial effort to find a suitable eastern base for its navy resulted in the founding of a British settlement in Penang (1786) and the occupation of the Andaman Islands (1788). The British seemed to have grasped the operational significance of the Strait of Malacca for the defense of India - the beginnings of their Second Empire. It was in this context that the founding of Singapore, located at the southern tip of the Malay Peninsula southeast of the Strait of Malacca, was strategically important for the British. ${ }^{1}$

The search for an eastern naval base coincided with an equally if not more important search for an eastern entrepôt. After the Seven Years' War, the East India Company had difficulty in paying for its expanding exports of silk and tea from Canton and sought to limit its shipments of silver to China by using Southeast Asian produce as an alternative form of payment. The East India Company also hoped to attract Chinese junks to an entrepôt outside the Cohong 公行 monopoly, where the terms of exchange would be more favorable to the British. ${ }^{2}$ Notwithstanding Penang's success, the East India Company still sought a place more central to the Strait of Malacca and to the South China Sea. The British sought Singapore already in the failed 1787 Anglo-Dutch negotiations after the Anglo-Dutch War (1780-1784), but the Dutch held out until the Anglo-Dutch Treaty of 1824, at which point they formally recognized the massive infiltration of British country traders in the Malay Peninsula from the 1760 s, concomitant with increasing British control over India. ${ }^{3}$

Many historians have asked why Singapore failed to be a major trading center before the nineteenth century. ${ }^{4}$ For Carl A. Trocki, Singapore rose, as

1 Wong 1991, pp.21-23. The Dutch defeat of the Bugis of Riau and Selangor frightened the British, who feared that the Dutch were about to dominate the Strait of Malacca. This impelled the Bengal administration to accept the Sultan of Kedah's offer of Penang in 1786 (see Bassett 1964, pp. 197-198). Although the East India Company had established a factory and garrison in Bencoolen (Palembang) on Sumatra's southwest coast as early as 1685 , Bencoolen was not on any major sea lane plied by Arab, Chinese, or European traders. The East India Company also tried to establish a factory in Balambagan in the Sulu Archipelago, where interethnic rivalry, pirate raids, and threats of Dutch and Spanish attacks doomed the settlement from the start (see Hack and Margolin 2010, p. 17, and Warren 1977, pp.73-93).

2 Bassett 1964, p. 197.

3 The country traders were private traders under license to trade east of the Cape of Good Hope. It was they who developed the opium trade, for the East India Company refrained from a trade interdicted by the Qing authorities. These traders were also encouraged to breach the Dutch monopoly of trade in the Dutch East Indies (see Wong 1978, p. 51). On British control over India, see Hack and Margolin 2010, p. 17.

4 Heng 2011, p. 27. 
a free port, only because opium revenues from British India provided lucrative and reliable flows of cash to the British and Dutch colonial governments of the East Indies. ${ }^{5}$ Another salient reason that historians have cited to explain its founding is that Singapore was the most convenient port of call for ships sailing from an Indian port down the Strait of Malacca or past the Sunda Strait and bound for China, Indochina, and Siam. ${ }^{6}$ Both explanations emphasize the relevance of India to the British colonization of Singapore. In this paper, I revisit the founding of Singapore to make two arguments. First, I argue that we cannot hope to understand the founding of Singapore and its role in the British Second Empire without defining Singapore as a forest- and marine-goods metropolis in the context of precolonial Chinese trading networks of Southeast Asia. Second, I attempt to show how the Chinese kongsis of West Borneo, which formed their own sociopolitical institutions, functioned collectively as a third autonomous pseudostate power alongside the British and the Dutch to help make Singapore a forest- and marine-goods metropolis in the context of competing, existing Dutch monopolies. With this groundwork, we can reconceptualize Singapore's founding as a joint enterprise, rather than as a solely British endeavor.

The West Borneo Chinese link to Singapore, "already plugged into some network, some process of circulation," was one of the "fragile threads" that connected the globe. ${ }^{7}$ Anthony Reid, to whom some scholars allude, regards the South China Sea as the "Asian Mediterranean," in which predominantly Hokkien Chinese-"merchants without empire" kinship ties with other Hokkien communities around the South China Sea. In doing so, they created a trade diaspora that linked a part of southern China with Southeast Asia. ${ }^{9}$ Yet, we ought to be aware of the parochialism of area studies, which often uncritically assume the unity of China, India, South Asia, or Southeast Asia in terms of some perceived cultural, ethnic, linguistic, and physical characteristics, ${ }^{10}$ even while acknowledging that Southeast Asian trade was part of a much larger commercial network around the Indian Ocean and South China Sea. ${ }^{11}$ Nor should we take for granted that Southeast Asia was part of Greater India, lest we fall prey to the same teleological divisions that, by emphasizing differences or exceptionalism, have plagued the historiography of modern nation-states. Taking as its point of departure Sanjay

5 Trocki 2002, p. 298.

6 Wong 1991, p. 44.

7 Subrahmanyam 1997, p. 762.

8 Wang 1990, pp.400-421.

9 Reid 1993; Li 2004, p. 2; Lockard 2010, pp. 219-228.

10 Subrahmanyam 1997, pp. 742-743.

11 Lockard 2010, p. 226. 
Subrahmanyam's notion of connectedness, this paper reinforces the argument that the activities of non-Europeans were crucial to the overall effectiveness of European empires as global systems sustaining regional and interregional networks within them. ${ }^{12}$ The Chinese communities in Borneo-largely Hakka, not Hokkien - were hardly insulated from global developments, including the founding of Singapore, from which they derived renewed strength to resist increasing Dutch dominance in Borneo.

A word is in order regarding my sources. This paper is an opinion piece that proposes placing Singapore in a key position in West Borneo's trade of the early nineteenth century. It is based only on secondary sources: no archives, no empirical data, no eyewitness descriptions, and no statistics. Nevertheless, it refers to an earlier period when Singapore was important for West Borneo. We already know from the current scholarly literature that Singapore played a pivotal role in West Borneo's colonial economy in the late nineteenth century and during much of the twentieth century. From such premises, this paper reconsiders the establishment of Singapore by the British from a wider, global, economic perspective and relates the Chinese kongsis of West Borneo to this setting. I aim here to inspire archival research into the relationship between the founding of the first kongsis (ca.1740) and the founding of colonial Singapore (1819), and into where trade was focused. The kind of goods involved in Singapore-West Borneo trade-foodstuffs, forest and marine products, gold, and labor-also deserves attention, but must await further studies for a more comprehensive treatment.

\section{Chinese Trading Networks and Early Colonial Singapore}

The idea that networks are crucial to linking human societies together has received much attention in past decades. ${ }^{13}$ However, some questions remain. In contrast to the usual emphasis on the role of merchants, how did Chinese laborers and indentured servants (coolies) - usually seen as mere commodities - figure in these networks? Did Chinese capitalism, or some form of it, ever lubricate these networks? Did the Chinese networks constitute a modernity parallel to European developments? Attempts to answer these questions may enable us to appreciate the role of Chinese trading networks in Southeast Asia.

To be sure, Chinese coolies did not enter Southeast Asia until after the Opium War (1839-1842), which allowed the British access to the Chinese labor force. ${ }^{14}$ Before that, when the Chinese entered Southeast Asia as

12 Frost 2005, p. 30.

13 Curtin 1984; Chang and Tagliacozzo 2011, pp. 1-2.

14 Farley 1968, pp. 257-270; Lockard 2013, p. 771. The Chinese and Indian reservoirs 
laborers rather than as traders, they were often miners in the service of native polities. In many parts of Southeast Asia, kings and nobles had mined, smelted, and worked copper, gold, iron, and tin into ornaments, utensils, and weapons since the first century, although copper and iron remained relatively scarce on the islands of Southeast Asia. ${ }^{15}$ A considerable supply of the world's tin was concentrated in the hills from eastern Burma to the Malay Peninsula, while gold deposits existed in Borneo, Sumatra, and the Malay Peninsula. ${ }^{16}$ From around the seventeenth century, Chinese laborers arrived in Batavia and Manila to produce sugar for regional markets. During the MingQing transition, thousands of Fujian and Guangdong Chinese escaped to Cochinchina, Cambodia, and the Gulf of Siam, where they grew pepper, rice, and other cash crops to cater to the demand of the South China market. Local kings or sultans usually arranged for Chinese farmers and miners to pay an annual lease or a percentage of their yields, and obliged Chinese to buy their supplies of arak, food, opium, and tools at inflated prices from themselves, although by the late eighteenth century, the Chinese started procuring their provisions from Southeast Chinese traders, who in turn paid import duties to the local rulers. ${ }^{17}$

Trocki contends that the growth of Chinese capitalism in nineteenthcentury Southeast Asia was connected to Chinese merchants' participation in the financing and operation of opium farm concessions. According to him, before the nineteenth century, production for export was inevitably handwork that yielded the actual producer little cash income for labor. Without commercial forms of production, finance, banking, and legal protection, which the Europeans would later provide, wealth could not effectively exist without the protection of power elites from the absolute and arbitrary rule of local kings and sultans. ${ }^{18}$ But Trocki's argument is, in essence, a reiteration of the European justification for colonization, which alleges that colonized societies did not possess the institutions and laws of "civilized nation-states" and that Europeans needed to mobilize their labor and resources for capitalist competition. ${ }^{19}$ In reality, however, across early modern Asia, Europe, and the Atlantic, imperial sovereignty was less a uniform system than a composite patchwork of competing and overlapping empires, governments, and jurisdic-

of indentured servants, amid much criticism in Britain, became important after the abolition of slavery in the British Empire in 1834 (see McKeown 2011, p. 67).

15 Reid 2011, pp. 22-23.

16 Reid 2011, pp. 25, 27.

17 Kwee 2013, pp. 19-20.

18 Trocki 2002, pp. 297, 299.

19 Duara 2008, p. 326. 
tions. ${ }^{20}$ If capitalism and capitalist economic organizations could not exist apart from Western capitalism, then the history of precapitalist economic organizations ends with the coming of capitalism in the guise of colonialism, imperialism, dependent development, or commercial capitalism. ${ }^{21}$ But this argument is problematic because Chinese capital did fuel the efficiency of Chinese industry in South China, and this pushed the maritime European nation-states toward specialization in commercial services, not the other way round. ${ }^{22}$

More than a decade ago, Subrahmanyam argued that scholars neglected the history of institutions in Southeast Asia and engaged in a "near-systematic refusal" to analyze social groups or types. As a result, according to Subrahmanyam, historians have largely followed Anthony Reid's lead in making only two distinctions for the region's social organization: between males and females, and between slaves and freemen. ${ }^{23}$ Since then, few scholars have taken Subrahmanyam's cue to study the social organizations in Southeast Asia, let alone reconciling Southeast Asian studies with China studies. ${ }^{24}$ Although Craig A. Lockard discusses the trade diaspora of Chinese merchants who linked southeastern China with Southeast Asia, his focus falls on the Hokkiens, whom he regards as the main drivers of cultural and economic exchanges between South China and Southeast Asia. ${ }^{25}$ Hence, a third distinction between the Chinese (not necessarily the Hokkiens) and indigenes, while not entirely accurate, is useful for placing subjects in perspective. ${ }^{26}$

Mark Frost points out that Chinese born or permanently settled beyond

20 Elliot 2006, p. 118; Subrahmanyam 2007, p. 1359; Stern 2013, p. 26.

21 Hamilton and Chang 2003, p. 174.

22 Pomeranz 2000; Chaudhuri 1978, pp. 153-160. For the Indian case, especially in the cotton industry, see Parthasarathi 2011. Trocki arrives at his conclusion because he did not consider South China in his analysis of Chinese capital in Southeast Asia. Nevertheless, he does acknowledge that European institutions did not interface with Southeast Asian economies, and that the Chinese were largely the ones who created capitalist institutions and forms of organization in the region in the nineteenth century (see Trocki 2002, p.299).

23 Subrahmanyam 1998, p. 98.

24 Kwee Hui Kian (2007) is a clear exception. Eric Tagliacozzo (2011, pp. 433-434) has raised a similar concern. A dated yet relevant study (Yen 1986, pp. 35-109) yields the impression that nineteenth-century Chinese communities of Southeast Asia, more specifically those of Malaya and Singapore, were largely characterized by clan and dialect organizations.

25 Lockard 2010, pp. 219-247.

26 The conceptual polarity of Chinese versus indigenes is inaccurate, for the division was blurred in all parts of early modern Southeast Asia from Siam to Vietnam (see Subrahmanyam 1998, p.98). 
mainland Chinese borders, such as those "domiciled in the increasingly Chinese city of Singapore," freely interacted with newer Chinese arrivals across a whole range of public institutions and spaces. He thus shifts our attention away from creolized or hybrid intermediary communities such as the Straits (or Peranakan) Chinese. ${ }^{27}$ So many Chinese migrants arrived in Southeast Asia in the eighteenth century that Trocki has dubbed it a "Chinese century" in the regional economies. ${ }^{28}$ As Chinese trader-settlers received more capital from the Europeans, they started to buy more opium from India and sold ever more ceramics, silks, and tea from China in large quantities. A partnership between local-born Straits Chinese, who interacted with Europeans, and new Chinese arrivals, who supplied products, became more established. Through much of the nineteenth century, Chinese junks continued to be heavily involved in transshipment across the South China Sea, carrying human cargoes of migrant labor on their outward voyages and products on the return leg. Attracted by trade in Singapore free of Qing Chinese and Dutch restrictions, junk traders and merchants relocated to the newly founded British settlement from southeastern China, the Malay Archipelago and Peninsula, the East Indies, and other parts of Southeast Asia, encouraging more trade along existing Bugis and Chinese trade routes linking these places. ${ }^{29}$

After the Napoleonic Wars, the British restored the East Indies to the Dutch and tolerated the Dutch reimposition of its monopoly on almost all trade with the archipelago. As the British saw it, spoils from the East Indies were essential to rebuilding and stabilizing Holland, a buffer state in continental Europe, ravaged during the wars. ${ }^{30}$ To enforce that monopoly, the Dutch often harassed foreign ships in their waters and refused to serve those that entered foreign ports. Both the East India Company and the British country traders suffered from the Dutch monopoly, and Singapore's founding provided them and regional merchants an alternative trading site to break Dutch control. ${ }^{31}$ On his part, Stamford Raffles, the founder of Singapore, created a system of government with nearly all real power in the hands of the colonial governor. Raffles also made Singapore an entrepôt, rather than a

27 Frost 2005, pp. 33-34.

28 Trocki 1997, pp. 83-101.

29 Frost 2005, pp. 34-37.

30 Tagliacozzo 2004, p. 29. Country traders, quite naturally, had a different opinion, preferring to pillage all the marine products of the East Indies over sharing London's geopolitical considerations (see Keay 1991, pp.442-443).

31 Yet, the British did not end their search for an eastern entrepôt with Singapore. They contemplated for a while whether they should form an emporium in the Gulf of Siam, which was closer to the large Chinese and Siamese markets (see Crawfurd 1915 [1821], p. 164). 
place where many goods were produced, and hence relieved it of the need for the coercive labor-control measures widely used in Java and India. ${ }^{32}$

Chinese merchants conducted the trade of Cambodian, Siamese, and Vietnamese polities with Singapore. Rulers of these polities generally distrusted the armed Europeans and preferred to entrust trade almost entirely to the Chinese. On their part, they provided the Chinese with cheap materials and workers to build shipping vessels. ${ }^{33}$ Siamese and Vietnamese rice, salt, and sugar flowed into strategically placed Singapore in exchange for British and Indian cloth, opium, and manufactures. ${ }^{34}$ British country traders too could unload their cargoes in Singapore, where they could trade with Chinese and other merchants without fear of the depredations of local rulers and state monopolies. In addition, Singapore lies strategically between Bangkok and Batavia along a north-south axis, where most of the major kongsi settlements in Southeast Asia were located. In short, Singapore became the center of the Chinese economy of Southeast Asia. ${ }^{35}$

\section{The Chinese Kongsis of West Borneo}

Trocki defines kongsi 公司 as a generic Chinese term for a range of economic and social configurations that includes everything from business partnerships to clan and regional associations to secret triad societies - a kind of corporation or "company" in which a group of individuals pooled economic resources and thus received a share in the enterprise. ${ }^{36}$ Many

32 This was different from how the East India Company ruled its possessions. Essentially, the East India Company acted over a coalition of landlords, merchants, and princes. East India Company governors styled themselves as merchant princes, who often consulted with indigenous elites (the "cannibals") and obtained trade goods by direct force against local, nonelite populations rather than free contracting. Country traders were the ones pressuring London to keep Singapore no matter what the Dutch said or did (see Pomeranz and Topik 2006, pp. 58-62). The founding of Singapore evolved from Raffles's keen awareness of the island as the site of an ancient commercial center for the Malay world, from which the British could centralize Malay revival (see Skott 2010, pp. 155-184). Not all of Raffles's contemporaries shared his view that Singapore had been an ancient site. For one, John Crawford (the ship's captain who came with Raffles on his first voyage, not the second Resident of Singapore) argued that no remains were seen to prove that Singapore was an ancient city and fort (see Miksic 2013, pp.412-414).

33 It cost Chinese shipbuilders only half as much to build their vessels in Siam as it did in Fujian or Guangdong (see Reid 2004, p. 31).

34 Wong 1960, pp. 134-143.

35 Trocki 2011, p. 93.

36 As a short synthesis of past studies, suffice it to say that the earliest gold and tin miners who arrived in Southeast Asia from China operated in shareholding partnerships, to which each worker would contribute his labor and a sum of money. The pooled capital was used for construction materials for lodgings and drainage facili- 
kongsis were formed as partnerships between laborers at one mine or plantation and the investor who supplied capital in the form of provisions, tools, and transport. ${ }^{37}$ Yen Ching-hwang narrows his definition to dialect associations that served the political, religious, and social needs of their constituents in Southeast Asia. ${ }^{38}$ A useful definition here, offered by Lockard, has it that a kongsi is a self-governing community based on clan relationships with a democratic spirit, with members electing representative assemblies and a governing council-a definition that is neither too broad nor too narrow. 39

In 1885, the Dutch colonial official and sinologist J. J. M. de Groot published the Chinese text and Dutch translation of the history of Lanfang Kongsi, arguing that the kongsi federations were not secret societies. De Groot appealed to the Dutch to retain the kongsi federation as a form of indirect rule for the Chinese, just as the Dayaks and Malays of Borneo were under indirect rule through local chiefs. Since he exaggerated the "republican" nature of the Chinese settlements, De Groot failed to realize that kongsis were first and foremost economic enterprises and farmers were second-class members, as were indigenes. One or a few family names controlled most federations, headmen remained in office for years, and the job sometimes passed from father to son or son-in-law. Suffice it to say that while sultans controlled the mouths of rivers, where Malay settlements were located, and the Dayaks populated the interior, the kongsis by the end of the eighteenth century came to control the upland river valleys north of Borneo. By the early nineteenth century, the larger kongsi federations were virtually independent of the sultans, who had invited the Chinese migrants to mine in the first place..$^{40}$

ties, as well as foodstuffs and other provisions throughout the mining period (see Kwee 2013, p. 20).

37 Trocki 1990, p. 11; Trocki 2002, p.301. As Trocki elaborates, the kongsi was a uniquely Chinese institution that evolved to conduct every kind of business. The term first came into use in the late seventeenth or early eighteenth century, referring to most settlements of Chinese laborers in Southeast Asia around 1700 and later for any kind of shareholding enterprise. Kongsis were essentially organized for economic purposes, legal or not (see Trocki 1990, p. 12, and Trocki 2007, p. 3). Kwee Hui Kian subscribes to Trocki's definition and understands kongsis as organizations (see Kwee 2013, p. 618, n. 7).

38 Yen 1986, pp.44-56.

39 Lockard 2013, p. 771. "Democratic" can be a problematic term because Chinese experiences were obviously different from Western ones. Nevertheless, this definition serves the purpose here of explaining kongsi as an economic and political organization independent of state control.

40 Heidhues 1992, pp.68-88. For excellent studies on Chinese kongsis in Borneo based largely on Dutch East India Company sources, see Heidhues 1992, Yuan 2000, and Heidhues 2003. For concise studies on Lanfang Kongsi per se, see Zhu 1960 and Luo 1961. 
The Lanfang Kongsi, or Lanfang Republic (1775-1884), was arguably the most prominent kongsi in West Borneo. It was established by Luo Fangbo (1738-1795), who arrived in Pontianak in western Borneo with a group of Hakkas from southeastern China, forged cordial relations with the local sultans, divided territories, settled disputes, collected taxes, built roads, supplied fresh water, and provided security. The "ritual brotherhood" that Luo Fangbo pioneered was soon emulated in other parts of West Borneo, and the kongsi system became effective in administering local governance. To put the establishment of the Lanfang Kongsi in perspective, West Borneo was marred by armed conflicts between Chinese factions, often based on dialect and home area in China. Luo Fangbo's effective governance gained him more followers over time and augmented his power through a mix of military conquests and political alliances. ${ }^{41}$ The longevity of the Lanfang Kongsi is telling of its effectiveness: it did not fall to the Dutch until $1884 .{ }^{42}$

The Hakkas were latecomers on the scene of South China and had encountered hostility and discrimination from early settlers of the Chinese coastal area and Southeast Asia. Thus for them, group consciousness became stronger than in other dialect groups in the region. A particular group of Hakkas, from Jiaying in South China, the hometown of Luo Fangbo, were arguably the founders of the "republican" kongsi system, which, according to Yen (1986, p. 44), stimulated the migration of Hakkas not only to West Borneo but also to other parts of Southeast Asia, including Malacca, Penang, and Singapore. ${ }^{43}$ However, we have no figures or accounts to prove that Hakka migrants arrived in Southeast Asia because of the success that they saw in the Borneo kongsis. Nevertheless, it seems that a constant stream of Hakka Chinese to West Borneo did provide the Lanfang Kongsi with both scholars (largely failures in the civil examinations, like Luo Fangbo) and miner-laborers (who wanted to escape from abject poverty in mainland China). Throughout its history, Lanfang Kongsi enjoyed an uneasy alliance with the Sultan of Sambas, who possessed the gold mines and demanded taxes from the kong-

41 Blusse and Merens (1993) extensively document the activities of Luo Fangbo.

42 Yuan 2000, pp. 47-55; Trocki 1990, p. 16; Reid 2004, pp. 24-25; Lockard 2013, p. 771. The British did not make serious attempts to sustain the lucrative traffic between Borneo and Singapore in the context of Dutch monopolies in the East Indies after 1824, and especially after the Opium War, when forest and marine products became less important than opium in the British trade with Qing China. The gradual success of longtime, persistent Dutch embargoes hampered BorneoSingapore trade even further (see Earl 1971 [1837], pp. 289, 305-307).

43 The West Borneo kongsis consisted almost entirely of people from four of the Hakkaspeaking districts in China's Guangdong Province: Jiaying (Meixian), Dapu, Jieyang (Hepo), and Huilai (Hailu-feng) (see Chin 1981, p.17). Yuan Bingling (2000) straightforwardly calls the Borneo kongsis "Chinese democracies." 
sis. ${ }^{44}$ At times, Lanfang suppressed local rebellions of Dayaks and other kongsis for the Sultan. Other times, Lanfang held its own elections of officials (although elected men were always influential, rich men in individual villages) to head or staff the customs offices, tribunals (according to the Qing legal code), gold mines, and even arsenals. Lanfang and some other kongsis manufactured their own cannons, guns, and ammunition, much to the chagrin and suspicion of local rulers. Lanfang also threatened local rulers' monopoly of food supplies by acquiring its own food supplies, which it made available to miners of its own and other Chinese settlements at much lower prices. It also competed with local rulers for forest produce to build roads, maintain waterways, and exploit natural resources. ${ }^{45}$

The largest existential threat to the kongsi always came from the Dutch, and not the local rulers. For instance, for several decades in the nineteenth century, the Dutch, in order to maintain their monopoly of the spice trade in the East Indies, tried, to little avail, to dissuade the Borneo sultans from selling pepper, which the Chinese would export to China and other parts of Southeast Asia, to the kongsis. ${ }^{46}$ The Dutch attempted to blockade the West Borneo coast and interdicted commercial intercourse between Chinese territories and foreign countries, except through the medium of their settlements in Pontianak and Sambas. ${ }^{47}$ In May 1853, the Dutch military command of West Borneo, with the tacit, coerced support of the local rulers, finally succeeded in imposing an embargo on opium, rice, salt, and other foodstuffs supplied to the kongsis, threatening harsh punishments on violators of the embargo and in the process criminalizing the kongsis as "rebels." 48 Till then, however, the kongsis benefited from a prosperous trade with the newly founded British

44 The Dayaks served as valuable part-time workers in the gold mines (see Reid 2011, p. 26).

45 Lanfang had only an informal social contract mutually understood by all. Luo Fangbo entertained the idea of attaching his realm to Qing China, but the Qing court never invested him with any title or formally recognized him as the ruler of West Borneo. Nevertheless, throughout Lanfang's history, scholars from China were invited to West Borneo to teach the Confucian classics (see Chin 1981, pp. 17-21, and Reid 2004, pp. 24-25). The inhabitants of Chinese commercial and mining towns were almost exclusively Chinese (see Earl 1971 [1837], pp. 210, 222).

46 Chin 1981, p. 8. Capitalizing on succession disputes and power intrigues in native politics, the Dutch first gained a stronghold in Borneo in 1785 through treaties with local rulers (see Crawfurd 1971 [1856], p. 65).

47 Earl 1971 [1837], p. 212. According to G. W. Earl (1971 [1837], p. 244), "the Chinese, unwarlike except in defense of their property, and unacknowledged by a mother country which could protect them from the aggressions of a cruel and rapacious enemy [the Dutch], were soon reduced from a state of affluence and prosperity, to the most abject poverty and wretchedness."

Yuan 2000, p. 231. 
settlement of Singapore, which had, to some extent, prolonged their existence, especially that of Lanfang.

\section{Trade between Early Colonial Singapore and the West Borneo Kongsis} The second British Resident of Singapore (1823-1826), John Crawfurd (1783-1868), wrote,

[The Chinese] are found in scattered numbers in every part of the coast of Borneo, but it is only on the western side, attracted thither by its gold and diamonds, that they exist concentrated and in large numbers. A portion of these is subject to the Dutch rule, paying a capitation-tax; but the majority are virtually independent, living under a kind of rude republic, governed by elective chiefs who administer the laws of China. No females, as is well known, emigrate from China; but the settlers have found wives among the women of the Dayaks, and hence many of the present colonists are a mestizo or mixed race; the original blood being, however, to some extent kept up by annual immigrations from China. The original settlers, as well as the present immigrants, are natives of the province of Canton, and all of the lower or working classes of society. The Dutch authorities have estimated their numbers, on the western coast alone, at $130,000.49$

One interesting observation made by Crawfurd - arguably the real founder of Singapore ${ }^{50}$ - was that despite local rulers' expulsion of the British from their factory in South Borneo in the early eighteenth century, in the first half of the nineteenth century there was British trade with Borneo "which is carried on chiefly with the free port of Singapore, and which not only far exceeds in value the Dutch and English trade of the 18th, but the trade of the Dutch in the 19th century, although [the Dutch are] exercising sovereign authority over two-thirds of the island." 51

When Singapore was first established as a regional entrepôt, trading vessels sailed regularly from Borneo to Singapore with various jungle produce: beeswax, bird's nests, camphor, pearls, pepper, sago, and tortoise-

49 Crawfurd 1971 [1856], p. 62.

50 Ernest C. T. Chew (1991, p. 39) asserts that it was not Raffles but Crawfurd who, after the Anglo-Dutch Treaty of 1824, received the necessary authorization from British India recognizing the British position in Singapore. Crawfurd's treaty with the Malay rajas, finalized on August 2, 1824, secured the cession of Singapore in "full sovereignty and property to the East India Company, its heirs and successors."

51 Crawfurd (1971 [1856], pp.65-66) concluded that all European attempts to establish territorial dominion in Borneo would be baffled by "the insuperable obstacles of an uncongenial climate, a stubborn soil, a rude and an intractable population, and the absence of all adequate financial resources." 
shells. In 1824, forty prahu from Borneo called at Singapore. Bugis and Malay traders from Borneo also participated in this trade with Singapore. Borneo's cargoes were sold off to Straits and South Chinese merchants in Singapore in exchange for Madras cloth, iron, steel, Chinese gold thread, Bengal and European chintzes, and long cloths - all to be retailed in the interior of Borneo. It was estimated that Singapore's trade with West Borneo amounted to around 60,000 to 70,000 Spanish dollars annually. The kongsi mining settlements of Sambas, Mampawa, and Pontianak exported gold dust to Singapore, for which they received smuggled opium, weapons, and salt. Without Singapore, the Dutch could have turned salt and opium-necessities for Chinese miners - into lucrative revenue monopolies. ${ }^{52}$ In other words, at the fortuitous moment of Dutch expansion in Borneo, which threatened the existence of the kongsis, Singapore allowed the Borneo Chinese to bypass the Dutch and local rulers to obtain higher-quality, cheaper supplies of essential goods. ${ }^{53}$ The West Borneo Chinese intensified their efforts at establishing a "permanent commercial intercourse" with Singapore in the 1830s, and Chinese merchants in Singapore were also eager to sell their opium, tea, and other articles for the produce of the gold mines, among other commodities, of Borneo. ${ }^{54}$ Chinese traders also sought after Borneo's camphor and rice, reputed to be of the highest quality. 55

Indeed, as a result of its proximity to Singapore and hence British influence, West Borneo quickly became a source of concern to the Dutch in the East Indies. However, Dutch ambitions were thwarted by the increasingly powerful kongsis, which circumvented their trade embargoes and restrictions and acquired Western arms and Southeast Asian raw materials mainly from Singapore. Heavy cannons of Arab origin and armaments from Singapore allowed the Chinese to resist the Dutch in armed conflicts. ${ }^{56}$ The growing importance of the traders from Singapore also damaged the interests of Malay merchants, who had been allowed to monopolize the trade in opium. At the insistence of the Sultan of Sambas, Dutch patrol boats intercepted Chinese smuggling boats in a major offensive in 1831. As a result, not without some

52 The West Borneo Chinese sold gold dust in terms of silver dollars, the price depending on the presumed purity of the gold, which differed according to where it was mined (see Heidhues 2003, p.50). For a concise description of the Borneo-Singapore trade, see Daniel Chew 1990, p.58, and Heidhues 2003, pp. 78-79.

53 Archaeological evidence reveals that the main items that circulated in the Singapore trade were ceramics and glass, which written sources barely mention (see Miksic 2013, p. 415).

54 Armenians in Singapore also tried to forge trade links with the Borneo Chinese (see Earl 1971 [1837], pp. 199-200, 316-317).

55 Earl 1971 [1837], pp. 248-250, 310-311.

56 Yuan 2000, p. 84. 
irony, the Chinese asked the Sultan to mediate between them and the Dutch. ${ }^{57}$ Nevertheless, Chinese smuggling activities continued, and Chinese sojourners and traders started to trade their coastal or trading products in the main towns and rural up-river areas - the Malay sphere of influence in Borneo - and Malay commerce experienced a gradual demise by the midnineteenth century. 58

Qing Chinese intense demand for cheap, foreign silver-largely the result of domestic rejection of worthless paper currency and a monetary system in which economic transactions were conducted and tax payments were made in silver-led to a steady rise in silver imports into China in the first half of the eighteenth century. However, after 1750, when the value of silver declined in China in comparison with Europe, Europeans, such as British merchants who arrived in Canton for tea, quickly pivoted and brought in Indian opium instead. Robert Hellyer argues that steady demand from China for forest and marine products, either unavailable at home or not produced in sufficient amounts to satisfy Chinese consumers, played an equally if not more prominent role in trade than simple fluctuations in the value of silver. According to Hellyer, Chinese demand for such goods shaped maritime trade throughout the South China Sea and Pacific from 1750 to 1850 and continued to do so even after opium gained increasing significance after 1820. Southeast Asian products included seaweed, sea cucumbers, shark's fins, abalone, bird's nests, sandalwood, Borneo camphor, and tortoiseshells. ${ }^{59}$

In Southeast Asian trade, we have to distinguish marine products, spices, and "all things Southeast Asian." The Dutch East India Company monopoly in the East Indies greatly affected the world spice trade. Yet, scholars have long established that despite the monopoly, the spice trade was indeed pivotal to the global trade of premodern times. Here I limit my discussion of past China-Southeast Asian trade to the western half of the Malay Archipelago, a much neglected cousin of the famed Spice Islands. The islands of Borneo, Java, and Sumatra produced their fair share of spices and, more important, forest and marine products, as noticed by some scholars. ${ }^{60}$ After 1750, demand intensified, first for Southeast Asian products that could be sold in China or Europe and then for goods that could be sold to the newly established communities of Chinese producers within Southeast Asia itself. Chinese and Europeans intensified their involvement to the exclusion of indi-

57 Yuan 2000, p. 146.

58 Daniel Chew 1990, p. 60.

59 The Japanese also participated in this maritime trade by supplying silver or transshipping Southeast Asian products (through Ryukyu) for sale in China and vice versa (see Hellyer 2013, pp.394-401).

60 Lieberman 1997; Tagliacozzo 2004; Hellyer 2013. 
genes, including the Bugis, who had earlier ousted the Malays in Riau and Selangor. ${ }^{61}$ Kongsis displayed the most economic and political independence of Chinese communal organizations in Southeast Asia from the enfeebled Malay polities around them. In fact, according to Victor Lieberman and Trocki, Singapore's founding sealed an informal compact between the Chinese and the British, with the Malay chiefs and their Bugis clients (among others) losing all legitimate claim to political power and status in Singapore and the area around it after $1824 .{ }^{62}$ As both Southeast Asian Chinese and British traders were grappling with the declining value of silver, forest and marine goods of the "West" East Indies provided them with an answer to maintain their China trade profits while allowing them to circumvent Dutch monopolies.

One main competitor, other than Japanese traders in Ryukyu, was the Sulu Sultanate, which, through the combination of free and forced labor, created a lucrative system for acquiring marine products. ${ }^{63}$ The Europeans, especially the British, demanded marine goods acceptable in Chinese markets and thus drove a rapid expansion in the Sulu economy in the second half of the eighteenth century. As Hellyer succinctly notes, the British decision to reduce silver in its trade with China, the British demand for more tea, and the limited Chinese demand for British cotton and woolen manufactures together caused socioeconomic ripples throughout Southeast Asia. ${ }^{64}$ Such ripples led Alexander Dalrymple (1737-1808) to develop the first plan for an entrepôt, in Balambangan near Sulu to attract Chinese, Bugis, Malay, and neighboring traders to bring forest and marine products to Balambangan. ${ }^{65}$ When the Balambangan settlement failed, the British regrouped in the Strait of Malacca and joined with the Dutch and Spaniards to extinguish "piracy" and hence Sulu - a main obstacle to their China trade. ${ }^{66}$

Eric Tagliacozzo calls Singapore a "marine goods metropolis"-an extended Indian port that allowed other British traders to bypass the East India Company monopoly on the China trade since the seventeenth century. European cargoes in Singapore in the 1820s included marine goods picked up

61 Lieberman 1997, p. 44.

62 See Trocki 2007, pp.65-74, and Lieberman 1997, p. 44.

63 Warren 1981; Hellyer 2013, pp.397-399.

64 Hellyer 2013, p. 399.

65 Warren 1977.

66 Lieberman 1997, p. 44. As Trocki (2007, p. 6) noted, Malay and other Southeast Asian seafarers were not "pirates" in the European sense of the word. I would add that Europeans and other peoples had different legal systems that authorized or legitimated certain "privileges" or "rights" by prosecuting or "outlawing" those of others. Legal pluralism, the coexistence of two or more legal systems, is a nascent field that deserves our interest (see Benton and Ross 2013). 
in small entrepôts and feeder centers all over the Malay Archipelago to supplement the staple goods of trade already stowed below from Europe and India. ${ }^{67}$ Chinese junks and Bugis prahus docked at Singapore with shark fins, pearls, sea slugs, and live turtles from all over the East Indies: Bali, Flores, Lombok, New Guinea, Sumbawa, and Timor. 68

One possible reason why the Borneo Chinese could succeed in the regional trade of forest and marine products - other than the natural endowments of their environment-was that the forest and marine commodities, with the clear exception of pearls, were particularly difficult to manage and subject to monopoly. Highly localized spice production was especially amenable to monopoly, while forest and marine goods had dispersed collecting zones and multiple potential exchange sites. The Chinese might not do the collecting themselves, preferring to procure the products from local collectors, harvesters, and fishermen - an act that the Europeans condemned as "smuggling." The Dutch could not break into the commodity chain at any level. Not only were the Dutch ineffective in controlling production zones, they also could not compete in the various markets, ranging from beachside barter to wholesale deals in ports. 69

To benefit from the vast Chinese market, the people of Borneo living in inland mountains began to harvest more forest products for Chinese consumers, including beeswax, Borneo camphor, and bird's nests. Trade expanded because of the constant demand from European merchants for silver substitutes..$^{70}$ Such developments coincided with the "industrious revolution" of northwestern Europe and North America roughly from 1650 to 1850, in which a growing number of households reallocated their productive resources - chiefly the time of their members - to increase market-oriented, money-earning activities and goods offered in the marketplace. When tea was incorporated into European social patterns and meals, demand grew exponentially, rising from negligible levels in 1700 to almost one million kilograms per year by 1720. With the opening of direct trade of tea from Canton, imports rose at a rate of 3.9 percent per year until the 1790s, when European consumption averaged 14.5 million kilograms annually. ${ }^{71}$ The impetus to innovate could be seen in the West Borneo Chinese (or anyone in Southeast

67 Tagliacozzo 2004, pp. 29-32.

68 Tagliacozzo 2004, p.31.

69 Holding onto the principle of buying cheap and selling dear, the Dutch East India Company capped the amounts officials could offer, so the Chinese always outbid them (see Sutherland 2011, pp. 178-184).

70 Hellyer 2013, p. 401.

71 De Vries 2008, pp. 10, 156. See also Pomeranz 2000 for an explanation of a similar "industrious revolution" in late imperial China. 
Asia hoping to profit from the maritime trade around them), who were addicted to the market and hence more willing than subsistence producers to work intensively for long periods. In short, consumption mattered. It produced new forms of state and systems of knowledge linking major global societies in economic, ideological, and social development. ${ }^{72}$ What Europeans as a whole did was to connect and subjugate industrious revolutions of other parts of the world, and it was for this large purpose that the British founded Singapore.

To recapitulate, with the founding of Singapore, Chinese, Bugis, Malay, and other regional traders started to supply Singapore with island productsforest and marine goods - suitable for reexport to China and elsewhere. These traders then supplied the islands of Southeast Asia with Chinese goods and with products of European industrial technology when such products were available in Singapore. Philip D. Curtin explains how the British experiment of replacing chartered companies, armed trade diaspora, and coercive monopolies with a free-port and trading-post empire worked in Singapore. The system developed through stages: Singapore first became a major node for Cantonese and Hokkien trade diasporas; it then started to serve as a base for the economic enterprises of local Chinese capitalists exploiting the resources of the Malay Peninsula; and it later became a settlement for southern Chinese. ${ }^{73}$ British imperialism was a global phenomenon governed by global conditions, with power derived less from the assertion of imperial authority than from the fusion of several disparate elements. This intricate web of British connections was constantly under the stress of geopolitical change. A change in one area could have a ripple effect on other areas, if not the whole empire. Hence, the British Empire, seen in this light, is better understood as the British world-system. ${ }^{74}$ As an entrepôt colony, Singapore was part of this system. As active agents and carriers of Singapore's entrepôt trade, especially in the regional trade of forest and marine products, the West Borneo Chinese and kongsis as well were under the stress of geopolitical change.

\section{Conclusion}

Speaking of British trade in the first half of the nineteenth century, Sir John Robert Seeley wrote,

Our trade . . . continued to be insignificant in spite of all our conquests [in India] until about 1813, and it began to advance with great rapidity soon after 1830. These dates point to the true cause of progress in trade,

72 Bayly 2004.

73 Curtin 1984, pp. 166, 240-242.

74 Darwin 2009, pp. xi-xii. 
and they show that it is wholly independent of progress in conquest, for they are the dates of the successive Acts of Parliament by which the Company was deprived of its monopoly. Thus it appears that, while it was by the East India Company that India was conquered, it was not by the East India Company, but rather by the destruction of the East India Company, that the great trade with India was brought into existence. Our conquests in India were made by an exclusive chartered Company, but our Indian trade did not greatly prosper until that Company ceased practically to operate. ${ }^{75}$

Similarly, though the East India Company seized Singapore-more accurately, Raffles secured Singapore for the East India Company without the company's knowledge - the China trade prospered for British country traders, Chinese kongsis and middlemen, and Bugis and Malay traders in the free port of Singapore, without the constraints and coercion of semiofficial company monopolies.

One question remains unanswered: how should we understand the West Borneo Chinese who settled in a foreign land and established a configuration of forces and means to govern themselves? As Timothy Mitchell puts it, more global pictures of cases such as Singapore make possible a less Eurocentric account of the formation of the modern world, an account made necessary by the fact that modernity had its origins in networks of exchange and production encircling the world and was born not in the West but of interactions between West and non-West. ${ }^{76}$ One site of such interactions was the East Indies. In the creation of the kongsis and the free port of Singapore, the "decisive nature of the distinction between European and non-European" was fixed. ${ }^{77}$ Though modernity can claim to be universal, we can see in the kongsis an alternative, parallel institution that had its origins in old, established Chinese trading practices and new geopolitical exigencies in the frontier region that had adopted them. ${ }^{78}$ The Chinese and other regional traders had always engaged in free trade of some form, and as mentioned earlier, the founding of Singapore was actually a formalization of events and trends that had been going on for centuries.

Are we then to call the establishment of the free port of Singapore a

75 Seeley 2005 [1891], p. 265.

76 Mitchell 2000, p.2.

77 Mitchell 2000, p.3.

78 Chinese nationalists, for the past century, have been calling the Lanfang Republic the first republic in the world (see Zhu 1960, p. 1, and Luo 1961). The urge to see the "sprouts" or even "origins" of democracy somewhat betrays their intent to argue that the Chinese do not owe the West their notions of democracy and freedom, and hence modernity. 
modern innovation? The founding of Singapore was an obvious example of how the British appropriated local, indigenous systems not by military conquest but by compromising and negotiating with existing local economic and political power brokers. To head back to Subrahmanyam's notion of connected histories, modernity historically is a global, conjunctural phenomenon, "not a virus that spreads from one place to another." 79 Having briefly delineated some of the global processes that brought the otherwise isolated societies of Borneo, Singapore, and other parts of the East Indies into closer contact in the late eighteenth and early nineteenth centuries, we may want to try justifying Tagliacozzo's argument that forest and marine goods-as indigenous products instrumental to increasing British trade with China-provided Singapore with some advantages over the monopolized markets of Batavia and other neighboring ports, and helped transform it into the successful port it still is today. ${ }^{80}$ It is interesting to note that Singaporean authorities, in recent years, have taken an interest in the historical links between Singapore and the West Borneo Chinese. ${ }^{81}$ The legacy, it seems, is here to stay.

\section{Bibliography}

Bassett, D. K. 1964. "British Trade and Policy in Indonesia, 1760-1772." Bijdragen 120, no. 2: 197-223.

Bayly, C. A. 2004. The Birth of the Modern World, 1780-1914: Global Connections and Comparisons. Malden, MA: Blackwell.

Benton, Lauren, and Richard J. Ross (eds.). 2013. Legal Pluralism and Empires, 1500-1850. New York: New York University Press.

Blusse, Leonard, and Ank Merens. 1993. "Nuggets from the Gold Mines: Three Tales of the Ta-kang Kongsi of West-Kalimantan." In Conflict and Accommodation in Early Modern East Asia: Essays in Honour of Erik Zurcher, edited by Leonard Blusse and Harriet Zurndorfer. Leiden, Neth.: Brill, pp. 284-321.

Chang, Wen-Chin, and Eric Tagliacozzo. 2011. "Introduction: The Arc of Historical Commercial Relations between China and Southeast Asia." In Chinese Circulations: Capital, Commodities, and Networks in Southeast Asia, edited by Eric Tagliacozzo and Wen-Chin Chang, pp. 1-17. Durham, NC: Duke University Press.

Chaudhuri, K. N. 1978. The Trading World of Asia and the English East India

79 Subrahmanyam 1998, pp. 99-10.

80 Despite the efforts of Tagliacozzo, Hellyer, and other scholars, we lack precise records of the Borneo-Singapore trade.

81 The Singapore National Arts Council sponsors an ongoing arts and installation project - "Lan Fang Chronicles," begun in 2010 - to investigate the concept of "insignificant histories" and draw "subtle parallels" between the Hakka Chinese Lanfang Republic and the Singapore story (see http://lanfangchronicles.wordpress. com/, accessed May 13, 2015). 
Company. Cambridge: Cambridge University Press.

Chew, Daniel. 1990. Chinese Pioneers on the Sarawak Frontier, 1841-1941. Singapore: Oxford University Press.

Chew, Ernest C. T. 1991. "The Foundation of a British Settlement." In A History of Singapore, edited by Ernest C. T. Chew and Edwin Lee, pp.36-40. Singapore: Oxford University Press.

Chin, John M. 1981. The Sarawak Chinese. Kuala Lumpur: Oxford University Press.

Crawfurd, John. 1971 [1856]. A Descriptive Dictionary of the Indian Islands \& Adjacent Countries. Kuala Lumpur and Singapore: Oxford University Press.

Crawfurd, John. 1915 [1821]. The Crawfurd Papers: A Collection of Official Records Relating to the Mission of Dr. John Crawfurd Sent to Siam by the Government of India in the Year 1821. Bangkok: National Library.

Curtin, Philip D. 1984. Cross-Cultural Trade in World History. New York: Cambridge University Press.

Darwin, John. 2009. The Empire Project: The Rise and Fall of the British WorldSystem, 1830-1970. New York: Cambridge University Press.

De Vries, Jan. 2008. The Industrious Revolution: Consumer Behavior and the Household Economy, 1650 to the Present. New York: Cambridge University Press.

Duara, Prasenjit. 2008. "The Global and Regional Constitution of Nations: The View from East Asia." Nations and Nationalism 14, no. 2: 323-345.

Earl, G. W. 1971 [1837]. The Eastern Seas. Singapore and New York: Oxford University Press.

Elliot, J. H. 2006. Empires of the Atlantic World: Britain and Spain in America, 1492-1830. New Haven: Yale University Press.

Farley, M. Foster. 1968. "The Chinese Coolie Trade, 1845-1875.” Journal of Asian and African Studies 3, no. 1-2: 257-270.

Frost, Mark Ravinder. 2005. "Emporium in Imperio: Nanyang Networks and the Straits Chinese in Singapore, 1819-1914." Journal of Southeast Asian Studies 36, no. 1: 29-66.

Hack, Karl, and Jean-Louis Margolin. 2010. "Singapore: Reinventing the Global City." In Singapore from Temasek to the 21st Century: Reinventing the Global City, edited by Karl Hack et al., pp.3-36. Singapore: NUS Press.

Hamilton, Gary G., and Wei-An Chang. 2003. "The Importance of Commerce in the Organization of China's Late Imperial Economy." In The Resurgence of East Asia: 500, 150, and 50 Year Perspectives, edited by Giovanni Arrighi et al., pp. 173-213. London and New York: Routledge.

Heidhues, Mary Somers. 1992. Bangka Tin and Mentok Pepper: Chinese Settlement on an Indonesian Island. Singapore: Institute of Southeast Asian Studies.

Heidhues, Mary Somers. 2003. Golddiggers, Farmers, and Traders in the "Chinese Districts" of West Kalimantan, Indonesia. Ithaca, NY: Southeast Asia Program, Cornell University. 
Hellyer, Robert. 2013. "The West, the East, and the Insular Middle: Trading Systems, Demand, and Labour in the Integration of the Pacific, 1750-1875." Journal of Global History 8, no. 3: 391-413.

Heng, Derek. 2011. "Situating Temasik within the Larger Regional Context: Maritime Asia and Malay State Formation in the Pre-modern Era." In Singapore in Global History, edited by Derek Heng and Syed Muhd Khairudin Aljunied, pp. 27-50. Amsterdam: Amsterdam University Press.

Keay, John. 1991. The Honourable Company: A History of the English East India Company. London: HarperCollins.

Kwee, Hui Kian. 2007. "Pockets of Empire: Integrating the Studies on Social Organizations in Southeast China and Southeast Asia." Comparative Studies of South Asia, Africa, and the Middle East 27, no. 3: 616-632.

Kwee, Hui Kian. 2013. "Chinese Economic Dominance in Southeast Asia: A Longue Duree Perspective." Comparative Studies in Society and History 55, no. 1: 5-34.

"Lan Fang Chronicles.” http://lanfangchronicles.wordpress.com (accessed May 13, 2015).

Li, Tana. 2004. "The Water Frontier: An Introduction." In Water Frontier: Commerce and the Chinese in the Lower Mekong Region, 1750-1880, edited by Nola Cooke and Li Tana, pp. 1-17. Singapore: NUS Press.

Lieberman, Victor. 1997. "Mainland-Archipelagic Parallels and Contrasts, c. 17501850." In The Last Stand of Asian Autonomies: Responses to Modernity in the Diverse States of Southeast Asia and Korea, 1750-1900, edited by Anthony Reid, pp. 27-53. New York: St. Martin's Press.

Lockard, Craig A. 2010. "The Sea Common to All': Maritime Frontiers, Port Cities, and Chinese Traders in the Southeast Asian Age of Commerce, ca. 1400 1750." Journal of World History 21, no. 2: 219-247.

Lockard, Craig A. 2013. "Chinese Migration and Settlement in Southeast Asia before 1850: Making Fields from the Sea." History Compass 11, no. 9: 765-781.

Luo Xianglin 羅香林. 1961. Xi Poluozhou Luo Fangbo deng suojian gongheguo kao 西婆羅洲羅芳伯等所建共和國考 (An examination of the republic established by Luo Fangbo and others in West Borneo). Hong Kong: Zhongguo Xueshe.

McKeown, Adam. 2011. "The Social Life of Chinese Labor." In Chinese Circulations: Capital, Commodities, and Networks in Southeast Asia, edited by Eric Tagliacozzo and Wen-Chin Chang, pp.62-83. Durham, NC: Duke University Press.

Miksic, John N. 2013. Singapore and the Silk Road of the Sea, 1300-1800. Singapore: NUS Press.

Mitchell, Timothy. 2000. "The Stage of Modernity." In Questions of Modernity, edited by Timothy Mitchell, pp.1-34. Minneapolis: University of Minnesota Press.

Parthasarathi, Prasannan. 2011. Why Europe Grew Rich and Asia Did Not: Global Economic Divergence, 1600-1850. New York: Cambridge University Press.

Pomeranz, Kenneth. 2000. The Great Divergence: China, Europe, and the Making 
of the Modern World Economy. Princeton: Princeton University Press.

Pomeranz, Kenneth, and Steven Topik. 2006. The World That Trade Created: Society, Culture, and the World Economy, 1400 to the Present. New York: M. E. Sharpe.

Reid, Anthony. 1993. "The Origins of Revenue Farming in Southeast Asia." In The Rise and Fall of Revenue Farming: Business Elites and the Emergence of the Modern State in Southeast Asia, edited by John Butcher, pp. 69-79. New York: St. Martin's Press.

Reid, Anthony. 2004. "Chinese Trade and Southeast Asian Economic Expansion in the Later Eighteenth and Early Nineteenth Centuries: An Overview." In Water Frontier: Commerce and the Chinese in the Lower Mekong Region, 1750-1850, edited by Nola Cooke and Li Tana, pp.21-34. Singapore: NUS Press.

Reid, Anthony. 2011. "Chinese on the Mining Frontier in Southeast Asia." In Chinese Circulations: Capital, Commodities, and Networks in Southeast Asia, edited by Eric Tagliacozzo and Wen-Chin Chang, pp.21-36. Durham, NC: Duke University Press.

Seeley, John Robert. 2005 [1891]. The Expansion of England: Two Courses of Lectures. New York: Cosimo.

Skott, Christina. 2010. "Imagined Centrality: Sir Stamford Raffles and the Birth of Modern Singapore." In Singapore from Temasek to the 21st Century: Reinventing the Global City, edited by Karl Hack et al., pp.155-184. Singapore: NUS Press.

Stern, Philip J. 2013. “'Bundles of Hyphens': Corporations as Legal Communities in the Early Modern British Empire." In Legal Pluralism and Empires, 15001850, edited by Lauren Benton and Richard J. Ross, pp. 21-48. New York: New York University Press.

Subrahmanyam, Sanjay. 1997. "Connected Histories: Notes towards a Reconfiguration of Early Modern Eurasia." Modern Asian Studies 31, no. 3: 735-762.

Subrahmanyam, Sanjay. 1998. "Hearing Voices: Vignettes of Early Modernity in South Asia, 1400-1750." Daedalus 127, no. 3: 75-104.

Subrahmanyam, Sanjay. 2007. "Holding the World in Balance: The Connected Histories of the Iberian Overseas Empires, 1500-1640." American Historical Review 112, no. 5: 1359-1385.

Sutherland, Heather. 2011. "A Sino-Indonesian Commodity Chain: The Trade in Tortoiseshell in the Late Seventeenth and Eighteenth Centuries." In Chinese Circulations: Capital, Commodities, and Networks in Southeast Asia, edited by Eric Tagliacozzo and Wen-Chin Chang, pp.172-199. Durham, NC: Duke University Press.

Tagliacozzo, Eric. 2004. “A Necklace of Fins: Marine Goods Trading in Maritime Southeast Asia, 1780-1860." International Journal of Asian Studies 1, no. 1: 23-48.

Tagliacozzo, Eric. 2011. "A Sino-Southeast Asian Circuit: Ethnohistories of the Marine Goods Trade." In Chinese Circulations: Capital, Commodities, and Networks in Southeast Asia, edited by Eric Tagliacozzo and Wen-Chin Chang, pp.432-454. Durham, NC: Duke University Press. 
Trocki, Carl A. 1990. Opium and Empire: Chinese Society in Colonial Singapore, 1800-1910. Ithaca, NY: Cornell University Press.

Trocki, Carl A. 1997. "Chinese Pioneering in Eighteenth-Century Southeast Asia." In The Last Stand of Asian Autonomies: Responses to Modernity in the Diverse States of Southeast Asia and Korea, 1750-1900, edited by Anthony Reid, pp. 83-101. New York: St. Martin's Press.

Trocki, Carl A. 2002. "Opium and the Beginning of Chinese Capitalism in Southeast Asia." Journal of Southeast Asian Studies 33, no. 2: 297-314.

Trocki, Carl A. 2007 [1979]. Prince of Pirates: The Temenggongs and the Development of Johor and Singapore. Singapore: NUS Press.

Trocki, Carl A. 2011. "Opium as a Commodity in the Chinese Nanyang Trade." In Chinese Circulations: Capital, Commodities, and Networks in Southeast Asia, edited by Eric Tagliacozzo and Wen-Chin Chang, pp. 84-104. Durham, NC: Duke University Press.

Wang, Gungwu. 1990. "Merchants without Empire: The Hokkien Sojourning Communities." In The Rise of Merchant Empires: Long-Distance Trade in the Early Modern World, 1350-1750, edited by James D. Tracy, pp.400-421. New York: Cambridge University Press.

Warren, Jim. 1977. "Balambangan and the Rise of the Sulu Sultanate, 17721775." Journal of the Malaysian Branch of the Royal Asiatic Society 150, no. 1: 73-93.

Warren, Jim. 1981. The Sulu Zone, 1768-1898: The Dynamics of External Trade, Slavery, and Ethnicity in the Transformation of a Southeast Asian Maritime State. Singapore: NUS Press.

Wong, Lin Ken. 1960. "The Trade of Singapore, 1819-69." Journal of the Malaysian Branch of the Royal Asiatic Society 33, no. 4: 1-315.

Wong, Lin Ken. 1978. "Singapore: Its Growth as an Entrepôt Port, 1819-1941." Journal of Southeast Asian Studies 9, no. 1: 50-84.

Wong, Lin Ken. 1991. "The Strategic Significance of Singapore in Modern History." In A History of Singapore, edited by Ernest C. T. Chew and Edwin Lee, pp. 17-35. Singapore: Oxford University Press.

Yen, Ching-hwang. 1986. A Social History of the Chinese in Singapore and Malaya, 1800-1911. Singapore: Oxford University Press.

Yuan, Bingling. 2000. Chinese Democracies: A Study of the Kongsis of West Borneo (1776-1884). Leiden, Neth.: CNWS.

Zhu, Xiuxia 祝秀俠. 1960. Luo Fangbo yu Wu Yuansheng 羅芳伯與吳元盛 (Luo Fangbo and $\mathrm{Wu}$ Yuansheng). Taipei: Haiwai Wenku Chubanshe. 